\title{
The Determinants of Capital Structure: Empirical Analysis of Oil and Gas Firms during 2000-2015
}

\author{
Aws Yousef Shambor \\ University of Hull, UK \\ E-mail: shambouraws@gmail.com
}

Received: April 22, $2016 \quad$ Accepted: January 18, $2017 \quad$ Published: June 1, 2017

doi:10.5296/ajfa.v9i1.9359 URL: http://dx.doi.org/10.5296/ajfa.v9i1.9359

\begin{abstract}
This study investigates the capital structure determinants of 346 oil and gas firms that are the constituents of the Global Oil and Gas Index (OILGSWD) over the period of $2000-2015$, taking into account the effect of the Global Financial Crisis of 2007-2009 on the determinants of the capital structure. Thus, six firm level explanatory variables (namely: liquidity, profitability, growth, non-debt tax shield, tangibility and size) are selected and regressed against the appropriate capital structure measure, leverage, the ratio of total debt to book value of total assets. The data is collected from secondary sources depending on the data from the DataStream database. The major findings of the study indicate that tangibility, profitability, size, liquidity and non-debt tax shield are the significant determinants of capital structure of oil and gas firms, while growth is considered insignificant. The capital structure is analyzed in terms of the three main theories of capital structure: Trade-off theory, Pecking order theory, and Agency cost theory. Finally, the global financial crisis has to some extent a significant impact on the capital structure determinants of oil and gas firms and has no significant impact on liquidity, as indicated by the OLS regression analysis results.
\end{abstract}

Keywords: Capital structure, Global oil and gas index, leverage, tangibility, liquidity, size, profitability, growth, and the global financial crisis. 


\section{Introduction}

\subsection{Background of the Study}

Capital structure is a very important topic in corporate finance field since it has a very significant effect on the firm financial performance and efficiency. Pandey (2005) defines capital structure as a decision made by firms regarding suitable financing sources i.e. whether they should use external or internal resource of financing or both. According to Brealey and Myers (1991), the financing sources of any firm are equity, debt, or hybrid securities that the firm issues.

However, leverage is known as the amount of debt used by a firm to finance its assets is termed leverage; firms that have a lot of debt in their capital structure are called highly levered firms, while firms that have no debt are called unlevered firms. Overall, the capital structure decision focuses on both the impact of leverage and the impact of the different outcomes on the firm's value as well as the capital cost. It is one of the most significant decisions made by financial managers of any company. Maximizing the company shareholders' wealth with low cost of capital is considered the main objective of corporate financial managers.

Thus, capital structure is considered an efficient management tool for managing the capital cost. Once the cost of capital is minimal, the optimal capital structure is achieved. Therefore, investigating the determinants of capital structure is very important for reaching the optimal capital structure for any company. For this reason, the literature contains numerous studies conducted to examine the capital structure determinants in many countries and to find the similarities as well as the differences in capital structure choices among different countries and among different industries even in the same country. Example includes Bradley et al study in(1984), Rajan and Zingalesstudy in (1995), Ojah and Gwatidzo's study in (2009), and Muzir's study in (2011).

According to Bradley et al. (1984), there is a correlation between the industry nature that the firm operates in and the capital structure choice. Harris and Raviv (1991) state that the ratios of leverage seem to be nearly the same for firms that are in the same industry and dissimilar between different industries; Talberg et al. (2008) indicate that industry specific characteristics significantly affect the capital structure decision of a firm. According to Baker and Martin (2011), the effects of industry nature on capital structure decisions are very significant, either because firm financial managers utilize industry median leverage as a point of reference for the leverage of their own firms or because the effects of industry nature are a sign of a set of interrelated factors.

In view of this significance, this study examines the determinants of capital structure of oil and gas companies listed on the global index over the period of $2000-2015$, in order to describe the process of decision making on the capital structure for this industry, thus contributing to the existing literature of empirical research in the field of corporate finance. Additionally, in view of the fact that this study is about the determinants of capital structure choice over the period of 2000- 2015, the question arises "Is there any effect of the global 
financial crisis of 2007-2009on the financing decision?" To the best of the knowledge of the researcher, is no previous research has been conducted on investigating the impact of the global financial crisis of 2007-2009 on the capital structure choice in companies of the oil and gas industry. Particularly, this study examines the determinants of capital structure (leverage) by using the OLS regression model on the available data for three periods: the pre-crisis period of 2000-2006, during the crisis in 2007-2009 and, the post crisis period of 2010-2015as well as during the total period as a whole 2000-2015, in order to determine whether the 2007-2009 global financial crisis has any influence on the capital structure determinants of the oil and gas companies.

\subsection{Importance of the study}

Capital structure is one of the most debated topics in the field of corporate finance, and attracts many researchers to investigate it. Some researchers examine the capital structure choice of companies from different industries such as Jensen \& Langemeier (1966)'s study for agricultural companies, Long \& Malitz (1985)'s study and Titman \&Wessels (1988)'s study for manufacturing firms, and Wedig et al (1988)'s study about non-profit making hospitals; such studies give evidence that the industry nature has a significant impact on the capital structure choice as, indicated by Joseph Ooi (1999).

Nevertheless, the capital structure of oil and gas firms is still a relatively under-investigation part in the literature of capital structure. Actually, none till now has examined the determinants of capital structure choice of oil and gas firms over the period 2000-2015, taking into account the impact of the global financial crisis in the period 2007-2009 on the capital structure decision of the firms. As a result, this study tries to fill the gap in the literature by making a contribution to the growing body of investigational corporate financial research in the oil and gas industry. A base thereby set for further research and improvements into the capital structure decisions of the oil and gas industry.

\subsection{Research Objectives}

The main goal of this study is to investigate the capital structure determinants of a panel of 436oil and gas firms listed on the Global Index during the period 2000 - 2015, taking into account the impact, if any, of the global financial crisis of 2007-2009 on the capital structure choice of the firms studied. Particularly, this study is intended to:

- Identify the capital structure determinants of oil and gas firms.

- Show how profitability, growth, size, non-debt tax shield, liquidity and tangibility affect the capital structure decisions of oil and gas firms.

- Find out the capital structure theory that can best describe the capital structure decisions of oil and gas firms.

- Investigate the influence of the global financial crisis of 2007-2009 on capital structureof oil and gas firms. 


\subsection{Research Questions}

This study is conducted to answer the following two questions:

1- To what extent and do firm specific factors, namely, liquidity, non-debt tax shield, profitability, tangibility, size and growth determine the capital structure decisions of oil and gas firms?

2- Which theories of capital structure can best describe the capital structure choice of oil and gas firms?

3- Is there any impact of the global financial crisis of 2007-2009 on the determinant of the capital structure of oil and gas firms?

\subsection{Literature Review}

A huge volume of research has been conducted on investigating the capital structure decision. Modigliani and Miller's theory (1958) is considered the revolutionary theory in the capital structure studies. Since the appearance of this theory in 1958, several theories and studies have emerged that are in a partial agreement with the propositions of Modigliani and Miller's theory which concludes that financial policy is not significant, not useful and not related. Till now, no theory on debt and equity has been completely acknowledged as the best theory to describe the financing decisions of all companies, because of the unique characteristics of each company that make it difficult to establish one capital structure for all, according to Schwartz (1959). As a result, some studies are conducted on critically explaining capital structure theories, such as Afrasiabishaniet al. (2012); some criticize the weaknesses of the theories, such as the studies conducted by ChirinkoandSingha (2000) and Zhaoet al. (2004), and other studies are conducted to test the capital structure theories experimentally like the one that is conducted by Shyam-Sunder and Myers (1999).In this study, five significant theories in capital structure are described below: Modigliani and Miller, Trade-off theory, Pecking order theory, Agency cost theory, and Market timing theory.

\subsubsection{The Theory of Modigliani and Miller}

The central postulation of the theory of Modigliani\& Miller (1958) is known as "the irrelevance theorem" which suggests that profitability is what determines the company's value, not its capital structure; Modigliani \& Miller(1958) suggest that the company's value is free of capital structure and that a levered company's value is equal to that of an unlevered one. The second proposition of Modigliani \& Miller is that the expected rate of return on equity increases proportionately with the gearing ratio. The equity cost is equivalent to the capital cost of an unlevered company in addition to the difference between the capital cost of an unlevered company and the debt cost, weighted by the ratio of debt-equity. The third preposition is that new projects should be evaluated by weighted average cost of capital (WACC) which is constant regardless of gearing.

In fact, their theory is considered as the essential groundwork of the capital structure theories, even though it faces a great deal of criticism. One of the criticisms is that this theory is not appropriate for the current environment because it assumes that there is an ideal capital 
market that has no bankruptcy cost, no equity risk, no debt risk, no business cost, and no taxes. Certainly, there is no such an environment in reality (Handoo and Sharma, 2014).

However, in a later study, Modigliani and Miller (1963) take into account tax to modify their first published theory and conclude that a levered company's value is more than that is of an unlevered one and this value and the value of the tax shield are equal because of taking the factor of tax shield on debt into consideration. As mentioned in Handoo and Sharma (2014), a further modification (Modigliani and Miller, 1966) includes the impact of personal taxes which are categorized into tax on income from debt securities and tax on income from holdings shares. To summaries, Modigliani and Miller's theory is still the basic theory of capital structure, which opens extensive discussion in the capital structure topic.

\subsubsection{The Trade-off Theory}

The trade-off theory supposes that a company makes debt the major source of its financing in its capital structure. Using more debt is beneficial for a firm because the marginal value of tax on more debt compensates the financial cost of the extra debt; this is known as the tax shield or the deductible tax as indicated by Myers (1984, 2001). According to Myers (1984), this theory refers to the trade-off of the benefits of tax and the costs of financial distresses. Companies with high debt may be more exposed to bankruptcy or financial troubles if they are not able to acquire enough cash by their operational or financial activities to be able to cover their borrowings. In addition, a firm with heavy debt is exposed to pay interest payment, while a firm without debt would invest all its profit again, according to Modigliani and Miller (1958).One of the most significant disadvantages of making debt the main source of firm finance is that the possibility of financial distress rises. In addition, Brealey, Myers and Allen (2006) state that if the firm raises debt and it is reluctant benefit from tax shield, the firm can have bankruptcy and financial distresses without benefiting from raising debt. According to Myers (1984), firms that are financially risky are supposed to borrow less. Therefore, companies are supposed to assess the advantages as well as the costs resulting from financing by debt for maximizing their value.

\subsubsection{Pecking Order Theory}

This theory was presented by Myers \& Majluf (1984). Pecking order theory is one of the most significant theories explaining the capital structure choice. It supposes that a company likes to use its internal financing resources first, and then it uses the external sources of finance including debt and equity as the final resort for funding because equity is more costly compared to and the internal sources of finance, which are considered the cheapest. If the firm needs external financing sources, it prefers to issue stocks, which are considered costless and safer compared other external financing sources that are used as the last resort, according to Myers \& Majluf (1984). Thus, the cost of each source of finance, which is related to information asymmetryand the fact that using internal finance sources is easier and more available than external ones play important roles in making firms prefer internal finance sources over external ones. Thus, the financing hierarchy suggested by Pecking order theory means that the external and internal sources of firm finance are not ideal alternatives.Pecking order theory explains firms' financing decisions by considering the essential information 
asymmetry existing between the various parties of a firm such as managers, creditors, and external investors.

\subsection{Determinants of Capital Structure}

The literature has a plethora of research and studies conducted to investigate the determinants of capital structure in many countries, since the decision of a firm capital structure is one of the main and most significant decisions the managers make. Myers (1977)states that companies with a high amount of debt are expected to miss out on beneficial investment opportunities; thus, companies that look forward to better future growth will be encouraged to issue equity in order to fund their projects. DeAngelo and Masulis (1980) argue that companies with high non-debt tax shields will be less motivated to benefit from the debt's tax advantage, so they will take on less leverage. Furthermore, Myers and Majluf (1984) state that there is a positive relationship between leverage and the assets' collateral value; for reducing information asymmetries, companies should preferably sell secured debt. According to Titman (1988), specialized industry companies should have higher leverage compared to manufacturing companies. Similarly, large companies may take on higher leverage in order to be more diversified and thus, have lower bankruptcy risks, according to Anget al (1982).In fact, many studies are conducted to investigate the factors that play a role in shaping companies' debt policy; for example, Bancel and Mittoo (2011) indicate that level of interest rates, credit ratings, share price, flexibility, and tax advantage of debt all affect the financing decisions of companies in Europe. However, the determinants of capital structure vary from one industry to another and from one country to another, as the literature indicates.

\subsection{Empirical Studies}

The value of empirical studies that testthe capital structure theories is enormous. For example, Shyam-Sunder \& Myers (1999) investigate one hundred and fifty seven US firms over the period 1971-1989 to find out whether trade off theory or pecking order theory best explains the financing practices of the firms selected. In a similar study, Fama\& French (2002) investigate three thousand US firms over the period of 1965-1999 in order to test the applicability of pecking order and trade off theory by the selected firms. Both Shyam-Sunder \& Myers (1999) and Fama \& French (2002) find that their results support the pecking order theory's assumption that firms that have high profit have a tendency to have less leverage. However, the findings of a study conducted by Frank and Goyal (2003) are contrary to the pecking order theory's prophecies depending on their investigation of US public trade firms over the period 1971-1998. According to them, deficit financing is less strongly followed by net debt issues than the net equity issues; they notice that pecking order theory's relevance declines over time for all firms, regardless of size. For that reason, Frank \& Goyal (2009) conduct another study to investigate many crucial factors in giving explanation of the capital structure choice of an enormous number of US public trade firms. They find that most selected firms apply the trade-off theory in their capital structure and they find that there are some factors that positively influence leverage, such as size, collateral, median industry factors, top corporate income tax rate, change in total firm assets, asset tangibility, and Treasury bill rate. Conversely, it is found that there are some factors that negatively influence 
leverage, such as profitability, market to book ratio, financial constraints, dividend-paying, net operating loss, and bankruptcy risk.

Bevan and Danbolt(2004) conduct a study to investigate the determinants of the capital structure of 1054 firms in the United Kingdom over the period of 1991-1997, taking into consideration the impact on these determinants of time-invariant firm-specific heterogeneity. It is found that smaller firms have less short-term and long-term debt, compared to larger firms; profitability is negatively related to gearing, even thoughless profitable firms have less short-term bank borrowing than profitable firms, and tangibility is positively related to short-term bank borrowing, as well as all long-term debt elements. On the other hand, they find that growth has little influence on gearing.Additionally, Rajan \& Zingales (1995) conduct a study in order to examine the capital structure choice made bynon-financial firms in seven countries, namely, Canada, the USA, Japan, the UK, France, Germany, and Italy. They find that UK and Germany firms are less levered than firms in other countries. Also, they find that specific factors such as profitability, size, and asset tangibility significantly influence leverage; In particular, profitability is negatively correlated to leverage, while size and asset tangibility are positively correlated to leverage according to their investigated sample. In addition, Ozkan (2001) examines the capital structure determinants of 390 non-financial companies over the period of 1984-1996; it is found that liquidity, growth and profitability influence negatively on leverage. In addition, Khrawish and Khraiwesh (2010) conduct a study to investigate the determinants of the capital structure of 30 industrial companies in Jordan over the period of 2001-2005; it is found that size and tangibility are positively related to leverage whereas profitability is negatively related to leverage. Finally, Table 2.1 in the appendix gives a summary of past empirical studies conducted on the determinants of capital structure.

\section{Data and Methodology}

\subsection{Data sources and collection}

This study investigates the capital structure determinants of the Oil and Gas sector firms over the period 2000 - 2015.Mostprevious empirical studies examining significant relationships between leverage and determinants are based on generally quantitative data from financial materials. Similarly, this study investigates the data that is collected from secondary sources; in particular, it depends on the data from DataStream database. The sample of this study is a panel of357 non-financial firms categorized as Oil \& Gas companies. However, Companies that have any missing observations for any variable in the model during the period of the study are excluded; in fact, there are eleven companies with incomplete information. Thus, the final sample of this study includes only 346 firms and 4,181 observations in the regression analysis. To eliminate the effect of outliers, all variables are winsorized at the top and lowest 1\% levels. The 346 companies are categorized as follows : 57 in Oceania , 74 in Europe , 12 in Russia, 81 in Asia, 12 in South America, 9 in Africa, 83 in The United State, and 18 in the United Kingdom, as shown in table 3.1 in the appendix. 


\subsection{Data analysis procedures}

This study presents quantitative analysis as well as theoretical data analysis. To analyze the data, both descriptive time series statistics and correlations are used to examine the relationship between the considered variables. Furthermore, this study employs Multivariate Ordinary Least Square (OLS) regression in order to determine if there is a correlation between Leverage, the dependent variable, and the multiple independent variables (Tangibility, Size, Profitability, Non-debt tax shield, Growth and Liquidity). This study uses one regression equation to test the hypotheses created in relation to leverage and the firm-specific determinants. Moreover, Excel 2013is used to compute and feed suitable data into the STATA software, to assess the trustworthiness of the data, to test validity of the specified model and to analyze it.

\subsection{Model Specification}

This study investigates the determinants of capital structure of the companies listed on the global oil and gas index. To achieve this aim, a quantitative rather than qualitative method is used. Most of the existing empirical studies on capital structure use linear regression techniques with proxies for the determinant factors used to explain the variation in leverage ratios across firms. Thus, this study uses one multivariate ordinary least square (OLS) regression model to run the analysis of the data collected in order to test and analyze the relationship between the financial leverage and its determinant factors, since it is known that regression analysis is able to examine the associative correlation between the dependent variable and one or more independent variables. It identifies the relative significance of independent variables, calculates the values of the dependent variable and determines the form or structure of the relationship. In order to apply regression analysis, it is assumed that there are linear relationships between leverage and the seven firm-specific internal factors, the error term is independent, constant and under a normal distribution. The multivariate ordinary least square (OLS) regression model used in this study is defined as follows:

\section{The model equation is:}

Leverage $\left(\right.$ Firm $\left._{\mathrm{it}}\right)=\beta 0+\beta 1\left(\right.$ Tang $\left._{\mathrm{it}}\right)+\beta 2\left(\right.$ Prof $\left._{\mathrm{it}}\right)+\beta 3\left(\mathrm{Grow}_{\mathrm{it}}\right)+\beta 4\left(\mathrm{Size}_{\mathrm{it}}\right)+\beta 5\left(\mathrm{Liq}_{\mathrm{it}}\right)+$ $\beta 6\left(\mathrm{NDTS}_{\mathrm{it}}\right)+\varepsilon_{\text {it }}$

Where:

Standard coefficients and error term

$\mathrm{I}=$ Represent the individual companies $\mathrm{t}=$ Represent the year

$\beta_{0}=$ Coefficient of Intercept (Constant)

$\beta_{4}=$ Coefficient of Size

$\beta_{1}=$ Coefficient of Tangibility

$\beta_{5}=$ Coefficient of Liquidity

$\beta_{2}=$ Coefficient of Profitability

$\beta_{6}=$ Coefficient of Tax-shield

$\beta_{3}=$ Coefficient of Firm Growth

$\varepsilon=$ the Error Term 


\section{Macrothink}

\section{Dependent variable}

2017, Vol. 9, No. 1

$>$ TDA represents leverage, which is measured by the ratio of total debt to book value of total assets.

\section{Independent variables}

Tang represents tangibility of assets, measured by the ratio of fixed assets to total assets.

Prof represents profitability, measured by using the ratio of EBIT over total assets.

Grow represents Growth, measured by the percentage change of total assets.

Size represents size, measured by the natural logarithm of total assets.

Liq represents Liquidity, measured by the total current assets over total current liability.

NDTS represents Non-debt tax shield, measured by the ratio of annual depreciation expense to total assets.

\subsection{Definition and Measurement of Variables}

\section{Explanatory variables}

Based on the previous studies, the researcher limits himself to the study of seven firm-specific factors, namely, tangibility (TANG), size (SIZE), profitability (PROF), liquidity (LIQ), growth (GROW), and non-debt tax shield (NDTS). According to Hsiao (1985), applying panel data gives more efficient coefficients and facilitates reduction of collinearity among explanatory variables. Therefore, the effects of explanatory variables on leverage (dependent variable) are estimated by using panel data or time- series cross-sectional data. In addition, there is one dummy variable which refers to the effect of financial crisis of 2007-2009 on leverage.

\section{Dependent variable (leverage)}

According to Deesomsak et al. (2004), the literature has many alternative definitions of leverage depending on whether market values or book measures are used and depending also on whether only long-term debt or total debt is taken into account. Thus, there are the following definitions of leverage: the ratio of total debt to book value of assets (TDA), the ratio of total debt to market value of assets (TDM), the ratio of long term debt to market value of assets (LDM), and the ratio of long-term debt to book value of assets (LDA).This study uses the capital structure (leverage) as the dependent variable and it is defined as the ratio of total debt to book value of total assets (TDA), the same model used by Rajan and Zingales (1995) and Ozkan (2001).

\section{Independent variables}

The estimated variables used in this study as the independent variables to clarify variations in leverage are Tangibility, Profitability, Growth, Size, liquidity and Non-debt tax shield. In appendix, Table 3.2 shows the proxies used to measure the variables selected by the study according to literature. 


\subsection{Research Hypotheses}

The study hypotheses are:

H 1: There is a positive impact of tangibility of oil and gas firms on leverage.

H 2: $\quad$ There is a negative impact of profitability of oil and gas firms on leverage.

H 3: There is a negative impact of growth of oil and gas firms on leverage.

$\mathrm{H}$ 4: $\quad$ There is a positive impact of size of oil and gas firms on leverage.

H 5: $\quad$ There is a negative impact of liquidity of oil and gas firms on leverage.

H 6: $\quad$ There is a negative impact of NDTS of oil and gas firms on leverage.

H7: There is a strong impact of the global financial crisis in the period of 2007-2009 on the capital structure determinant of oil and gas firms, assets tangibility.

H8: There is a strong impact of the global financial crisis in the period of 2007-2009 on the capital structure determinant of oil and gas firms, profitability.

H9: There is a strong impact of the global financial crisis in the period of 2007-2009 on the capital structure determinant of oil and gas firms, growth.

H10: There is a strong impact of the global financial crisis in the period of 2007-2009 on the capital structure determinant of oil and gas firms, size.

H11: There is a strong impact of the global financial crisis in the period of 2007-2009 on the capital structure determinant of oil and gas firms, liquidity.

H12: There is a strong impact of the global financial crisis in the period of 2007-2009 on the capital structure determinant of oil and gas firms, non-debt tax shield.

H13: There is a strong impact of the global financial crisis in the period of 2007-2009 on the capital structure determinant of oil and gas firms, age.

\section{Results and Discussion}

\subsection{Data Testing}

In order to ensure that the available data of the study present reliable results and the model used fits the data, three tests are applied, which are normality, multicollinearity and heteroscedasticity tests. The three tests are related to the conventional linear regression model used for the selected data. Testing the data by these tests is required since Multivariate Ordinary Least Squares (OLS) is a technique for estimation that has many desirable properties; data testing verifies that the testing of hypotheses for the coefficient estimations is validly conducted.

\subsection{Descriptive Statistics}

Table 4.4, in the appendix, shows descriptive statistics for the values of the variables used after removal of extreme observations in the data selected. The data is now seen as disturbed, 
since removal of some estimations leads to an irregular distribution. In Table 4.4, contains the following information: the number of observations, Number of firms, Mean, Median, Standard deviation, Minimum and Maximum of one dependent variable (TDA) and seven explanatory variables which are : Tangibility, Profitability, Growth, Size, Liquidity and NDTS. The data consists of a panel of 346 firms.

0 The total debt ratio (TDA), which is "the average ratio of total debt to book value of total assets" of Oil and Gas firms is found to be 0.2457 , which means that only $24.6 \%$ of the firms' funds is provided by borrowing and the other $75.4 \%$ is provided by other financing sources. It can be said that the capital structure of the selected firms is not heavily dependent on debt.According to Frank and Goyal (2009), getting an average leverage at book value of $0.29 \%$ means that the firms investigated are fairly low leveraged.

o The asset tangibility mean is found to be $52.3 \%$, which indicates that the oil and gas fixed assets represent $52.3 \%$ of the total assets, since the business nature of oil and gas business is distinguished by having high fixed assets. Tangibility of the oil and gas firms is measured by the ratio of fixed assets to total assets.

0 The annual average of profitability of the Oil and Gas firms investigated is found to be 9.2\%. Because the ratio of Earnings Before Interest, Tax and Depreciation (EBITD)to total assets is used as a proxy to measure profitability, the maximum average profitability rate is $4 \%$ while the lowest recorded average profitability rate is $-2.2 \%$, which indicates that the firms have a constant profitability rate every year.

o The size proxy used in this study is the assets logarithm. Consequently, the mean, maximum and minimum statistics make slight economic sense. Nevertheless, a bench mark variation of 2.687 reveals great dissimilarities in size between the investigated firms.

o Liquidity, which is defined as the ratio of current assets over current liabilities, is more than 1.5, indicating that the firms have some strength in facing financial distress because of this amount of liquidity and that they have the ability to meet this obligation. Since the selected firms are from the oil and gas industry, it is expected that they have relatively high fixed assets. Therefore, for every one unit of current liabilities, firms are found to have 1.78 unit of current assets in order to cover their short-term liabilities. In Ozkan's (2001) study, the achieved liquidity ratio of it's the sample is found to be 1.64 of current assets, which suggests that, by comparison, oil and gas firms are to some extent better at meeting their short-term obligations.

o The mean of Non-debt tax shield is found to be 0.047 . This finding is somewhat higher than the mean of 0.036 found by Ozkan (2001) although this study applies the same standard deviation used by Ozkan (2001), who reports a Non-debt tax shield isof0.020, which is lower than what is found in this study.

\subsection{Correlation Analysis}

Regression and correlation analyses are considered to be related to each other because they are both concerned with relationships among variables. The correlation coefficient stands for 
a measure of linear relationship between two variables. Correlation coefficient values range between -1 and +1 . A correlation coefficient of +1 shows that two variables are entirely related positively in a linear sense; whereas a correlation coefficient of -1shows that two variables are entirely related negatively in a linear sense. In contrast, a correlation coefficient of zero indicates that there is no linear relationship between the two variables at all. For simple linear regression, the coefficient of sample correlation is measured by the square root of the determination coefficient. The correlation coefficient is concerned only with measuring the level of linear relationship between two variables.

Table 4.5, in the appendix, shows that the ratio of total debt to book value of total assets is correlated at 0.249 with Tangibility, at the $1 \%$ significance level, at -0.238 with Profitability at the $1 \%$ significance level, at 0.030 with Growth, at the $5 \%$ significance level, at 0.072 with firm Size, at the $1 \%$ significance level, at -0.317 with Liquidity at the $1 \%$ significance level, at -0.081 with Non-debt tax shield at the $1 \%$ significance level.

In addition, Table 4.5 indicates that tangibility, size, and growth positively influence leverage whereas profitability, liquidity and non-debt tax shield negatively influence leverage. Also, it is found that size, NDTS and growth are positively correlated to profitability while tangibility and liquidity are negatively correlated to profitability. This means that larger oil and gas firms are disposed to have higher profitability. To conclude, the explanatory variables chosen are found to have a significant and strong association with the dependent variable, TDA. For that reason, the independent variables chosen can explain the dependent variable to a significant degree.

\subsection{Multivariate Regression Analysis}

This section aims at analyzing the regression model results. Multiple regression analysis on the cross sectional data is carried out in order to investigate the instantaneous impact of all the independent variables on the dependent variable.

The multivariate linear regression model before estimation is:

Leverage $\left(\right.$ Firm $\left._{\mathrm{it}}\right)=\beta 0+\beta 1\left(\right.$ Tang $\left._{\mathrm{it}}\right)+\beta 2\left(\right.$ Prof $\left._{\mathrm{it}}\right)+\beta 3\left(\mathrm{Grow}_{\mathrm{it}}\right)+\beta 4\left(\mathrm{Size}_{\mathrm{it}}\right)+\beta 5\left(\mathrm{Liq}_{\mathrm{it}}\right)+$ $\beta 6\left(\mathrm{NDTS}_{\mathrm{it}}\right)+\varepsilon$

Table 4.6, in the appendix, represents the outcomes of the regression analysis in for each of the independent variables.

As shown in Table 4.6, R-squared is 0.2309 , which shows that about $23.09 \%$ of the variability of debt to equity ratio is explained by the chosen firm-specific factors. In other words, about $23.09 \%$ of the change in the dependent variable is explained by the independent variables that are included in the model.

The Estimated Regression Equation:

Leverage $=0.239+0.1639$ Tan -0.419 Pro +0.017 Grow +0.004 Size -0.025 Liq -1.053 NDTS $+\varepsilon$ 
4.5 The Relationship between Capital Structure Determinants and Leverage over the Whole Sample Period, 2000-2015.

\subsubsection{Leverage with Assets Tangibility}

The ratio of fixed asset to total assets is taken as a proxy for tangibility. The results of the regression model indicate that the correlation between leverage and asset structure is statistically significant at the level $1 \%$. The sign of the coefficient is positive; thus, when there is an increase in Tangibility by $1 \%$, debt will increase by 0.16 . This result is supports the first hypothesis (H1), namely, "There is a positive impact of tangibility of Oil and Gas firms on leverage". In addition, this findings is in line with the finding of many previous studies such as Jensen and Meckling (1976), Harris and Raviv (1991), Bennett and Donnelly (1993), Rajan and Zingales (1995), Gaud et al. (2003), and Frank and Goyal (2009). Rajan and Zingales (1995) state that firms with higher collateral assets are more likely to get a high level of debt in view of the fact that tangible assets are easy to collateralize and thus they reduce the agency cost of debt. Moreover, this finding is in line with the agency cost theory as debt providers demand securities as collateral to put them in more secure position. According to the pecking order theory, the information asymmetry is supposed to be lower for firms that have more tangible assets, which results in more debt. Conversely, Harris and Raviv(1991) state that tangibility negatively influences leverage as suggested by the pecking order theory; they suggest also firms that have few tangible assets are assumed to have more asymmetry troubles, and thus, the coefficient is not expected to be significant. However, the trade-off theory suggests that tangibility is positively correlated to leverage in view of the fact that a higher degree of asset tangibility leads to lower bankruptcy costs.

\subsubsection{Leverage with Profitability}

The ratio of EBITD to total assetsis taken as the proxy of profitability. Profitability is statistically significant at the $1 \%$ level. The sign of the coefficient is negative, which means that an increase in profitability by $1 \%$,will be associated with a decline in debt by $0.42 \%$. Thus, this result is in line with the second hypothesis $(\mathrm{H} 2)$, namely, "There is a negative impact of profitable of Oil and Gas firms on leverage". This means that the firms that are more profitable are the ones that have lower leverage. In other words, firms that have higher levels of profitability are likely to use less leverage in their capital structure. This behavior means that trade-off theory fails to explain the relationship between leverage and profitability. Trade-off theory argues that firms with high profit are likely to have higher leverage and more taxable income to shield, as stated by Barclay and Smith (2005). Our result gives more support to pecking order theory that implies that firms prefer to finance projects with internal funding. This finding is in line with many previous studies such as Rajan and Zingales (1995), Ozkan (2001), and Gaud et al. (2005) who state that profitability is negatively related to debt (leverage).

\subsubsection{Leverage with Growth Opportunity}

The ratio of percentage increase in total assets is taken as the proxy for growth opportunity. Growth opportunity is positively related to leverage. This positive coefficient means that a 
$1 \%$ change in growth rate measured by the percentage change in total assets leads to a 0.028 change in leverage ratio, and thus the variable is not significant. Consequently, the third hypothesis (H3), namely, "There is a negative impact of growth of Oil and Gas firms on leverage" is rejected. In addition, this finding is not in line with either Trade-off theory or Agency cost theory, while it supports Pecking order theory, which suggests that if firms have to depend on external financing sources, they would prefer to use debt over equity. This finding means that firms of oil and gas industry that have higher growth rate maintain higher leverage ratios. Thus, Growth is considered a significant factor that plays a key role in making the capital structure decisions in oil and gas sector; firms that have lower growth rates borrow less than firms that have high growth rates. Furthermore, this finding is in agreement with the findings of Beck and Demirguc-Kunt (2006) who find that small firms have greater growth restrictions and are less likely to use external financing sources, and with the finding of Michaelas et al. (1999) who state that small firms that are rapidly growing are likely to have insufficient earnings for financing all of their growth internally. This positive sign indicates that growing oil and gas firms are expected of to rely more on external borrowing, in order to grasp market opportunities. Therefore, there is a positive relationship between growth and leverage.

\subsubsection{Leverage with Size}

The natural logarithm of assets is taken as the proxy for size. According to the finding of this study, the result of beta coefficient that is related to size, the fourth hypothesis (H4), namely, "There is a positive impact of size of Oil and Gas firms on leverage" is accepted. This relation between size and leverage is in line with the trade-off theory. Large firms are highly leveraged for the reason that they have no fear of bankruptcy. Debt providers are also more willing to lend to larger firms because the instability of earnings in these firms is not very high and firms have the ability to pay back their debts. However, in case the firms do not have the ability to repay their debt, they have a high level of assets that can be used as collateral. Moreover, this finding is in agreement with many studies, for instance, O zkan (2001), Bevan and Danbolt (2004), and Frank and Goyal (2009), who all find that size is positively related to leverage; they all suggest that small firms should not depend on long term debts and instead, they should borrow short term, in case they are sure enough of being able to repay their debts. Because this study has chosen 346 firms in the oil and gas industry, and most of these firms are active all over the world with gigantic market capitalization, debt is positively correlated to size.

\subsubsection{Leverage with Liquidity}

The ratio of current assets to current liabilities is taken as a proxy of liquidity. Liquidity is statistically significant at the $1 \%$ level. The sign of its coefficient is negative, which means that liquidity negatively influences leverage. Thus, the fifth hypothesis (H5), namely, "There is a negative impact of liquidity of Oil and Gas firms on leverage" is accepted. This can be interpreted by the fact that when there is an increase in liquidity by $1 \%$, debt will decrease by $0.02 \%$. Thus, it can be concluded that borrowing in the selected oil and gas firms could be expensive and oil and gas firms prefer to finance their needed fund through their liquid assets. 
In the other words, firms that have higher liquidity prefer to use internal assets as a finance source; this is in agreement with Pecking Order Theory assumptions. In addition, it is found that in case of not having enough internal financing, oil and gas firms tend to choose equity financing as an alternative financing source. Thus, this finding is in line with Ozkan (2001), who states that liquidity is negatively related to debt. According to Ozkan (2001), this kind of relationship may arise from conflicts among shareholders. This could be interpreted by the fact that if firm shareholders attempt to change the price of firm assets for their personal benefits and impose the expenses on bond and stock holders, there will be a conflict. However, if firms have a consistent reserve of cash, there is no need to increase the debt. Money or Cash is constantly taken into account as the best indicator of liquidity. Therefore, it is assumed that large firms have more cash. In some critical situations like a recession, debt is considered a threat, to liquid assets. As a result, it is better for firms to have no borrowing.

\subsubsection{Leverage with Non-debt tax shield}

The ratio of annual depreciation expense to total assets is taken as a proxy for Non-debt tax shield. This study finds that non-debt tax shield is negatively related to leverage; the relationship is significant at the $1 \%$ level. Thus, the sixth hypothesis (H6), namely, "There is a negative impact of NDTS of Oil and Gas firms on leverage" is accepted. According to the finding that an increase in non-debt tax shields negatively affects leverage, non-debt tax shields are considered as an alternative for the tax benefits of leverage financing to depreciation, as suggested by Wald (1999).Oil and gas companies that are with higher non-debt tax shields are assumed to have less long-term debt in relative to other firms of other industries. According to Ozkan (2001), a non-debt tax shield is significant and inversely related to leverage. He suggests that firms that have a high level of non-debt tax shields that can be deducted from taxable income are supposed to have less debt compared to other firms, ceteris paribus. In a study conducted by DeAngelo and Masulis (1980), it is found that firms that have greater Non-debt tax deductions use less debt compared to equity. Therefore, this finding is in line with many previous studies such as Wald (1999), Wanzenried (2002), and Gaud et al. (2003).Also, it is consistent with trade-off theory, which suggests that when there is an increase in the amount of non-debt tax shield in a firm, debt would be not needed.

\subsection{The Effect of the Global Financial Crisis on the Capital Structure Determinants}

In order to investigate the impact of the global financial crisis on the determinants of capital structure of oil and gas firms, the study examines the potential effects of the crisis through dividing the study period into three different periods: namely, 2000-2006 as the pre-crisis period, 2007-2009 as the crisis period, and 2010 - 2015 as the post-crisis period. Then, this study implements the both the descriptive statistics analysis and the OLS regression analysis of the three different periods separately, as shown in table 4.7 and table 4.8 in the appendix.

\subsubsection{Descriptive Statistics}

In order to investigates if there is any impact of the financial crisis of 2007-2009 on the capital structure determinants of oil and gas firms in terms of the descriptive statistics, Mean, which is defined as the total of the observations divided by the total number of observations 
is examined during the three different periods: pre-crisis period, the crisis period, and the post crisis period. As shown in table 4.7 in the appendix, Mean of each variable is affected by the financial crisis. The difference of Mean value of each variable becomes less or more during the crisis. Particularly, the Mean of the Total debt ratio decreases slightly, from approximately 0.24 to 0.23 during the crisis and then it goes back to raise to become about 0.25 . The mean value of Profitability, size and liquidity go up during the crisis. The mean of both Profitability and liquidity go down again after the crisis while size continue to go up after the crisis. On the other hand, the mean value of tangibility, growth, and non-debt tax shields decrease slightly during the crisis. After the crisis, the mean of tangibility returns again approximately the same in the pre-crisis period. However, the mean of Growth goes down strongly to be 0.12 while it is $0.19,0.18$ in pre-crisis period and during the crisis period, respectively. To sum up, it is clear that the global financial crisis affect the mean value of the capital structure determinants of oil and gas firm.

\subsubsection{Regression Statistics}

The OLS regression analysis results illustrate whether the capital structure determinants of oil and gas firms become more or less significant when they are related to leverage during the crisis. The impact of the global financial crisis on the explanatory variables is illustrated in table 4.8 in the appendix .

\section{Assets Tangibility}

The results reveal that there is a positive relationship between tangibility and leverage, which is significant at the $1 \%$ level for all three periods. It is found that the coefficient of Tangible assets in the crisis period is almost $22 \%$, which is higher than in the pre-crisis period. This increase means that tangible assets had a greater impact on leverage during the financial crisis period, compared to its impact during the preceding period of economic expansion. In other words it is more important in the crisis period. According to Jimenez and Saurina (2004), mitigating the difficult selection problem that lenders face is considered the most important function of tangible assets. This problem was more difficult during the 2008 financial crisis; therefore, it seems reasonable that during the financial crisis, debt providers look for better quantity and quality of tangible assets to compensate as stated by Barrell and Davis (2008).For this reason, the need for security would make this variable have greater impact on firm leverage. Thus, it can be said that H8, namely, "There is a strong impact of the global financial crisis in the period of 2007-2009 on the capital structure determinant of oil and gas firms, Assets tangibility" is accepted.

\section{Profitability}

The results indicate that there is a negative relationship between Profitability and leverage, which is significant at the $1 \%$ level for all three periods. In addition, it is found that profitability has a relative decrease in relation to leverage, which suggests that it is less related to leverage in the crisis period, the coefficient of profitability during the crisis period is almost 35\% which is lower than the one in the pre-crisis period, when it is almost $54 \%$.Thus, profitability is less importance in relation to leverage during the crisis period. This 
implies that during the crisis period oil and gas firms with higher profitability were using less debt for financing, comparing with the pre-crisis period. Therefore, it can be said that H9, namely, "There is a strong impact of the global financial crisis in the period of 2007-2009 on the capital structure determinant of oil and gas firms, profitability" is accepted.

\section{Growth}

The results indicate that there is a positive relationship between growth and leverage and growth is statistically insignificant in the whole period of the study, 2000-2015. However, it is found that the relationship is insignificant in both the crisis period and post-crisis period, whereas it is statistically significant at the $10 \%$ level in the pre-crisis period. The positive relationship is in agreement with pecking-order theory, which suggests that companies that have high growth level will issue debt to mitigate the trouble of asymmetric information. However, growth in the pre-crisis period is different from that in the other periods, in that it is statistically significant at the $10 \%$ level. The coefficient of growth in the pre-crisis period is almost 3\%, which is higher than in the crisis and post crisis periods, when it is $1 \%$ and almost $2 \%$, respectively, which they are statistically insignificant. According to Baily and Elliott (2009), during difficult times where there is a decline in the economy, such as in case of a financial crisis, there would be less or no growth at all for some quarters. For that reason, growth is negatively related to leverage and has less importance in times of crisis. Thus, it can be said that H10, namely, "There is a strong impact of the global financial crisis in the period of 2007-2009 on the capital structure determinant of oil and gas firms, growth" is accepted.

\section{Size}

The results indicate that there is a positive relationship between size and leverage over the period of 2000-2015. Size is statistically significant at the $1 \%$ level for the whole period of the study. There is a slight difference in the level of size significance among the three different periods; size is significant at $1 \%$ for the pre-crisis and crisis periods while it is significant at the $5 \%$ level for the post crisis. However, the coefficient of size has a relative decrease in relation to leverage during the crisis period, compared to during the pre-crisis period; The coefficient of size in the pre-crisis period is almost $0.6 \%$ which is higher than in the crisis where the coefficient is almost $0.2 \%$.This implies that firm size is less related to leverage in the crisis period; thus it is less significant in relation to leverage during the crisis period. Therefore, it can be said that H11, namely, "There is a strong impact of the global financial crisis in the period of 2007-2009 on the capital structure determinant of oil and gas firms, size" is accepted.

\section{Liquidity}

The financial crisis starting in 2007 in the market of sub-prime credit caused a liquidity crisis in the short-term debt markets. In this difficult situation, firms tended to use this credit line mainly in order to deal with the unexpected liquidity shocks. In fact, several firms were straggly influenced by the decreasing demand for their products during the crisis period; however, they had no liquidity problems because they had large cash holdings, in the case of 
BP and BAKER HUGHES oil and gas firms, whose liquidity was not affected by the financial crisis. In this study, the relationship between liquidity and leverage is negative for all three periods and significant at $1 \%$. The coefficient of liquidity during the period of post crisis period is almost 4\%, which is higher than those in the pre-crisis and crisis periods, when in each period were almost $1 \%$. Thus, there is no impact of the global financial crisis on the coefficient of liquidity. Therefore, it can be said that H12, namely, "There is a strong impact of the global financial crisis in the period of 2007-2009 on the capital structure determinant of oil and gas firms, liquidity" is rejected.

\section{Non-debt tax shield}

In the pre-crisis period, many firms prefer debt financing because interest payments can be subtracted from corporate tax liability, which is known as a 'tax shield' whereby interest is deducted from firm profits before tax as stated by Miller and Modigliani (1958). If the firm is in profit, then this decreases the borrowing cost. Thus, the coefficient of NDTS is significantat the $1 \%$ levelfor all periods in this study and it is negatively related to leverage. It is found that the global financial crisis in the period of 2007-2009influences NDTSofoil and gas firms. The coefficient of NDTS increases strongly in the crisis and post crisis periods; it is -0.53 in the pre-crisis period while it is -1.27 and -1.35 in the crisis period and post crisis period, respectively. This implies that firm NDTS is more related to leverage during the post crisis period. Therefore, it can be said that H13, namely, "There is a strong impact of the global financial crisis in the period of 2007-2009 on the capital structure determinant of oil and gas firms, Non-debt tax shield" is accepted.

\subsection{Test of the Consistency with Capital Structure Theories}

One of the aims of this study is to find out which of the capital structure theories best explains the financing decisions of oil and gas firms investigated over the period of 2000-2015.As mentioned before, this study is concerned with three capital structure theories, namely, Trade-off theory, Pecking order theory and Agency cost theory. The theories are different in terms of their traits in explaining the corporate capital structure. The trade-off theory assumes that the optimal capital structure is a trade-off between bankruptcy costs and the net tax benefit of using debt as a main finance source. Firms that have high tangible assets are able to provide collateral for debts, so these firms can use more debt. Also, firms that are larger in size and have high profitability have high debt ratio and firms that have high growth opportunities rate use less debt. On the other hand, Pecking order theory suggests that a firm prefers internal financing sources to external financing ones and dangerous debt to equity because of the information asymmetries between shareholders and outsider investors. In addition, the third theory, Agency cost theory, gives an explanation of firms' financial behaviour in the context of agent and manager relationship.

Table 4.9, in the appendix, summarizes the hypothesized, expected and observed theoretical signs of the explanatory variables. Therefore, a test of the consistency with theory of the capital structure in the Oil and Gas firms is made relying on the expected and observed signs of the coefficients of the explanatory variables. Hence, this study concludes the following: 
Table 4.9 shows that all determinants of the capital structure choice of oil and gas firms except size and NDTS are in agreement with the Pecking order theory. Thus, it can now be announced that the Pecking order theory best explains the capital structure theory of oil and gas firms listed on the Global Oil and Gas Index over the period of 2000-2015.

\section{Conclusion}

Capital structure is still considered an important topic that attracts corporate managers and academics. This study explored the determinants of capital structure of 346 firms listed on the global oil and gas index over the period of 2000-2015. Pooled ordinary least squares (OLS) regression techniques were been used on panel data as well as using the statistical computer package of STATA. For this study, the total debt ratio is taken as a measure of leverage, the dependent variable. Also, liquidity, profitability, size, growth, non-debt shield, and tangibility are all selected to be independent variables. Additionally, this study examines the impact of the global financial crisis on the firm-specific determinants of capital structure of oil and gas firms.

Even since Miller and Modigliani's (1958) claim that capital structure is irrelevant to firm value, some theories that suggest the opposite have been developed. In this study, the main three capital structure theories, namely, trade-off theory, Pecking order theory and Agency cost theory are investigated to find out which one best explains the financial behavior of the selected firms since they give different explanations of the capital structure decision. Furthermore, literature has a lot of research and study about this topic conducted on many different countries as well as on many different determinants of the capital structure decision. Consequently, the primary objective of the study is to fill up the gap in the current literature by optimistically providing some helpful information and useful finding about the capital structure determinants of Oil and Gas firms.

According to the descriptive statistic, shown in Table 4.4, leverage, defined as the average ratio of total debt to book value of total assets (TDA), is found to be 0.246 , indicating that only $24.6 \%$ of the firms' funds is provided by borrowing and the other $75.4 \%$ is provided by other financing sources. Also, the results of the correlation matrix that are illustrated in Table 4.5 show the linear correlations between the chosen explanatory variables and leverage are significant. Furthermore, the regression results shown in Table 4.6 for the leverage determinants show that the $\mathrm{R}$ squared is 0.231 , which implies that $23.1 \%$ of the leverage variability firms is explained by the selected firm-specific factors.

Moreover, all the selected explanatory variables, are found to be the significant determinants of the capital structure of oil and gas firms. Conversely, it is found that profitability, liquidity, and Non-debt tax shield are negatively related to leverage while tangibility, growth and size are positively related to leverage. As a result, by testing the hypotheses, it can be said that the regression results of the coefficients of capital structure determinants support hypotheses 1,2 , 4,5 , and 6, whereas hypotheses 3 and 7 are rejected.

Additionally, this study covers the impact of the global financial crisis in the period of 2007-2009 on the capital structure determinants of oil and gas firms. In particular, this study 
investigates how much the capital structure is sensitive to its determinants, how it is changed, and what other ratios could have effects on the capital structure during the crisis period. The sample period is divided into three periods of interest: one is from 2000 to 2006, identified as the pre-crisis period, one from 2007 to 2009 , identified as the crisis period, and one from 2010-2015,identified as the post-crisis period.It is found that there is a strong impact of the global financial crisis in the period of 2007-2009 on all capital structure determinants of oil and gas firms except liquidity, where it is found that there is no significant impact at all. However, the other capital structure determinants become more or less significant when they are related to leverage during the crisis.

In addition, this study examines the capital structure of oil and gas firms in terms of the three main theories of capital structure, namely, Trade-off theory, Pecking order theory, and Agency cost theory. It is found that all the chosen determinant factors, except size and NDTS, of capital structure decisions made by the oil and gas firms are in line with the Pecking order theory. On the other hand, the positive effect of size on capital structure decision is found to be in accordance with both the Trade-off theory and Agency cost theory, and the sign of NDTS is found to be consistent with Trade-off theory predictions.

\section{References}

AbdWahab S., \& Ramli N. (2014). The Determinants of Capital Structure: An Empirical Investigation of Malaysian Listed Government Linked Companies. International Journal of Economics and Financial Issues, 4(4), 930-945.

Afrasiabishani J., Ahmadinia H., \& Hesami E. (2012). A Comprehensive Review on Capital Structure Theories. School of Doctoral Studies (European Union) Journal, 35-45.

Ang, J.S., Chua, J.H., \& McConnell, J.J. (1982). The Administrative Costs of Corporate Bankruptcy: A Note. Journal of Finance, 37, 219-226. https://doi.org/10.1111/j.1540-6261.1982.tb01104.x

Baily, M.N., and Elliott, D.J. (2009). The US Financial and Economic Crisis: Where Does it Stand and where do we go from Here?Business and Public Policy, pp: 1-26.

Baker H.K., \& Martin G.S., (2011). Capital Structure and Corporate Financing Decisions: theory, evidence and practice. John Wiley and Sons. Hoboken, New Jersey. https://doi.org/10.1002/9781118266250

Bancel F., \& Mittoo U.R., (2011). "Survey Evidence on Financing Decisions and Cost of Capital” In Kent Baker M., Maria, S. (Ed.), Capital Structure and Corporate Financing Decisions: Theory, Evidence, and Practice, Chapter 13, John Wiley and Sons Inc., 229-248. https://doi.org/10.1002/9781118266250.ch13

Barrell R., \& Davis P. E. (2008) .The Evolution of the Financial Crisis of 2007-8'. National Institute Economic Review, 206(5), 5-14. https://doi.org/10.1177/0027950108099838 
Beck T., \& Demirguc-Kunt A. (2006). Small and Medium-Size Enterprises: Access to Finance as a Growth Constraint. Journal of Banking and Finance, 30, 2931-2943. https://doi.org/10.1016/j.jbankfin.2006.05.009

Bennett, M., \& Donnelly R. (1993). The Determinants of Capital Structure: Some UK Evidence, British Accounting Review, 25, 43-59. https://doi.org/10.1006/bare.1993.1005

Bevan, A.A., \& Danbolt, J. (2002). Capital structure and its determinants in the United Kingdom - a decompositional analysis. Applied Financial Economics, 12(3), 159-170. https://doi.org/10.1080/09603100110090073

Bevan, A.A., \& Danbolt, J. (2004). Testing for Inconsistencies in the Estimation of UK Capital Structure Determinants. Applied Financial Economics, 14(1), 55-66. https://doi.org/10.1080/0960310042000164220

Bradley M., Jarrell G.A, \& Han Kim E. (1984). On the Existence of an Optimal Capital Structure: Theory and Evidence, Journal of Finance, 39(3), 857-878.

Brealey, R. \& Myers, C. (1991). Principles of Corporate Finance. 4th ed. New York: McGraw-Hill.

Brealey R.A., Myers S.C., and Allen F. (2006). Principles of Corporate Finance. $8^{\text {th }}$ edition, New York: McGraw Hill.

Chirinko R.S., \& Singha A.R. (2000). Testing Static Tradeoff against Pecking Order Models of Capital Structure: a Critical Comment. Journal of Financial Economic, 58, 417-425. https://doi.org/10.1016/S0304-405X(00)00078-7

Chung, K. H. (1993). Asset Characteristics and Corporate Debt Policy: an Empirical Investigation. ournalof Business Finance and Accounting, 20(1), 83-98. https://doi.org/10.1111/j.1468-5957.1993.tb00251.x

Dalbor A.U. (2001). An Examination of Capital Structure in the Restaurant Industry. International Journal of Contemporary Hospitality Management, 13(2), 54-59. https://doi.org/10.1108/09596110110381825

DeAngelo H. and Masulis R.W. (1980). Optimal Capital Structure under Corporate and Personal Taxation. Journal of Financial Economics, 8(1), 3-29. https://doi.org/10.1016/0304-405X(80)90019-7

Deesomsak, R., Paudyal, K. and Pescetto, G. (2004). The Determinants of Capital Structure: Evidence from the Asia Pacific Region. Journal of Multinational Financial Management. 14 (4-5). pp. 387-405. https://doi.org/10.1016/j.mulfin.2004.03.001

Deloof M., \& Verschueren I. (1998). The Determinants of Capital Structure of Enterprises in Belgium. Journal of Economics and Management, 42(2), 165-188.

Fama, E., \& French, K. (2002). Testing Trade-off and Pecking Order Predictions about Dividends and Debt. The Review of Financial Studies, 15(1), 1-33. https://doi.org/10.1093/rfs/15.1.1 
Frank M., \& Goyal V. (2003). Testing the Pecking Order Theory of Capital Structure. Journal of Financial Economics, 217-248. https://doi.org/10.1016/S0304-405X(02)00252-0

Frank M., \& Goyal V. (2009). Capital Structure Decisions: Which Factors are Reliably Important? $\quad$ Financial Management, $\quad 38, \quad$ 1-37. https://doi.org/10.1111/j.1755-053X.2009.01026.x

Gaud, P., Jani, E., Hoesli, M., \& Bender. (2005). The Capital Structure of Swiss Companies: An Empirical Analysis using Dynamic Panel Data. European Financial Management, 11, 51-69. https://doi.org/10.1111/j.1354-7798.2005.00275.x

Handoo A., \& Sharma K. (2014). A Study on Determinants of Capital Structure in India. IIMP Management Review, 26, 170-182. https://doi.org/10.1016/j.iimb.2014.07.009

Harris M., \& Raviv A. (1991). The Theory of Capital Structure. The Journal of Finance, 46, 297-355. https://doi.org/10.1111/j.1540-6261.1991.tb03753.x

Huang, G., \& Song, F. (2006). The Determinants of Capital Structure: Evidence from China. China Economic Review, 17(1), 14-36. https://doi.org/10.1016/j.chieco.2005.02.007

Jensen, F.E., \& Langemeier, N. (1966). Optimal Leverage with Risk Aversion: Empirical Evidence. Agricultural Finance Review, 55, https://doi.org/10.1016/0304-405X(76)90026-X

Jensen, M., \& Meckling, W. (1976). Theory of the Firm: Managerial Behaviour, Agency Costs and Ownership Structure. Journal of Financial Economics, 3, 305-360.

Jimenez G., \& Saurina J. (2004). Collateral, Type of Lender and Relationship Banking as Determinants of Credit Risk. Journal of Banking and Finance, 28(9), 2191-2212. https://doi.org/10.1016/j.jbankfin.2003.09.002

Joseph Ooi. (1999). The Determinants of Capital Structure Evidences on UK Property Companies. Journal of Property Investment \&Finance, 17(5), 464-480. https://doi.org/10.1108/14635789910294886

Khrawish H., \& Khraiwesh A. (2010). The Determinants of the Capital Structure: Evidence from Jordanian Industrial Companies. JKAU: Economics and Adminstration, 24(1), 173-196. https://doi.org/10.4197/eco.24-1.5

Long, M, \& Malitz, I. (1985). The Investment-Financing Nexus: Some Empirical Evidence. Midland Corporate Finance Journal, 3(3), 53-59.

Michaelas, N., Chittenden, F., \& Poutziouris P., (1999). Financial Policy and Capital Structure Choice in UK SMEs: Empirical Evidence from Company Panel Data. Small Business Economics, 12, 113-130. https://doi.org/10.1023/A:1008010724051

Modigliani F., \& Miller M.H. (1958). The Cost of Capital, Corporation Finance and the Theory of Investment. American Economic Review, 48(3), 261-297. 
Muzir E. (2011). Triangle Relationship among Firm Size, Capital Structure Choice and Financial Performance. Journal of Management Research, 11(2), 87- 98.

Myers, S.C. (1977). Determinants of Corporate Borrowing. Journal of Financial Economics, 5(2), 147-75. https://doi.org/10.1016/0304-405X(77)90015-0

Myers, S.C. (1984). The Capital Structure Puzzle. The Journal of Finance, 39, 575-592. https://doi.org/10.2307/2327916

Myers, S.C., \& Majluf N., (1984). Corporate Financing and Investment Decisions When Firms Have Information that Investors do not have. Journal of Financial Economics, 13, 187-221. https://doi.org/10.1016/0304-405X(84)90023-0

Najjar N., \& Petrov K. (2011). Capital Structure of Insurance Companies in Bahrain. International Journal of Business and Management, 6(11), 138-145. https://doi.org/10.5539/ijbm.v6n11p138

Ojah, K., \& Gwatidzo, T. (2009). Corporate Capital Structure Determinants: Evidence from Five African Countries. African Finance Journal, 11, 1-23. https://doi.org/10.1080/0960310042000319228

Ojah, K., \& Manrique, J. (2005). Determinants of Corporate Debt Structure in a Privately Dominated Debt Market: a Study of the Spanish Capital Market. Applied Financial Economics, 15, 455-468

Oke M., \& Obalade A. (2015). Testing the Validity of Optimal Capital Structure Theory in Nigerian Listed Oil Firms. International Journal of Economics, Commerce and Management, $3(3), 1-15$.

Ozkan, A. (2001). Determinants of Capital Structure and Adjustment to Long Run Target: Evidence from UK Company Panel Data. Journal of Business Finance and Accounting, 28, 175-198. https://doi.org/10.1111/1468-5957.00370

Padron, Y. G., Apolinaro, R. M. C., Santana, O. M., Conception, M., Martel, V., \& Sales, L. J. (2005). Determinant Factors of Leverage: An Empirical Analysis of Spanish Corporations". Journal of Risk Finance, 6(1), 60-68. https://doi.org/10.1108/15265940510581279

Pandey, I. M. (2005). Financial Mangemnt. 9th edition, Vikas Publishing House Pvt. Ltd., India.

Psillaki M., \& Daskalakis N. (2009). Are the Determinants of Capital Structure Country or Firm Specific?. Small Business Economics, Springer, 33(3), 319-333, October. https://doi.org/10.1007/s11187-008-9103-4

Rajan R., \& Zingales L. (1995). What do we know about the Capital Structure? Some Evidence from International Data. The Journal of Finance, 50, 1421-1460. https://doi.org/10.1111/j.1540-6261.1995.tb05184.x

Schwartz E. (1959). Theory of the Capital Structure of the Firm. The Journal of Finance, 14(1), 18-39. https://doi.org/10.1111/j.1540-6261.1959.tb00483.x 


\section{Macrothink}

Asian Journal of Finance \& Accounting

ISSN 1946-052X

2017, Vol. 9, No. 1

Shyam-Sunder L., \& Myers S. C. (1999). Testing Static Tradeoff against Pecking Order Models of Capital Structure. Journal of Financial Economics, 51, 219-244. https://doi.org/10.1016/S0304-405X(98)00051-8

Song, H. (2005). Capital Structure Determinants: An Empirical Study of Swedish Companies. The Royal Institute of technology Centre of Excellence for Science and Innovation Studies, January 2005. Available on line at: https://static.sys.kth.se/itm/wp/cesis/cesiswp25.pdf. Retrieved on 20th August 2015.

Sritharan, V. (2014). Determinants of Capital Structure - A Case Study of Listed Banks Financial and Insurance Companies in Colombo Stock Exchange in Sirlanka. International Journal of Economics, Commerce and Management, II(10), 1-18.

Talberg M., Winge C., Frydenberg S., \& Westgaard S., (2008). Capital Structure across Industries. International Journal of the Economics of Business, 15(2), 181-200. https://doi.org/10.1080/13571510802134304

Titman S., \& Wessels R. (1988). The Determinants of Capital Structure Choices. The Journal of Finance, 43, 1-19. https://doi.org/10.1111/j.1540-6261.1988.tb02585.x

Upneja A., \& Dalbor M.C. (2001). An Examination of Capital Structure in the Restaurant Industry. International Journal of Contemporary Hospitality Management, 13(2), 54-59. https://doi.org/10.1108/09596110110381825

Wald J.K. (1999). How Firms Characteristics Affect Capital Structure: An International Comparison. The Journal of Financial Research, 22(2), 161-187. https://doi.org/10.1111/j.1475-6803.1999.tb00721.x

Wanzenried G. (2002). Capital Structure Dynamics in UK and Continental Europe. Discussion writings dp0209, University of Bern, Department of Economics.

Wedig G. J., Sloan F.A., Hassan M. and Morrisey M.A. (1988). Capital Structure, Ownership, and Capital Payment Policy: The Case of Hospitals. The Journal of Finance, 43(1), 21-40.

Zhao J.,Katchova A., \& Berry P. (2004). Testing the Picking Order Theory and the Signalling Theory for Farm Businesses. Paper presented at the American Agricultural Economics Association Annual Meeting, Denver, Colorado, July 1-4 (2004). 


\section{Macrothink}

Asian Journal of Finance \& Accounting

ISSN 1946-052X

2017, Vol. 9, No. 1

\section{Appendix}

Table 2.1. Summary of Past Empirical Studies. (Arranged Alphabetically)

\begin{tabular}{|c|c|c|c|c|c|c|c|c|c|c|c|}
\hline \multirow{2}{*}{ Author } & \multirow{2}{*}{$\begin{array}{c}\text { Data } \\
\text { Period }\end{array}$} & \multirow{2}{*}{ Focus } & \multirow{2}{*}{ Journal } & \multirow{2}{*}{ Sample } & \multirow{2}{*}{$\begin{array}{l}\text { Dependent } \\
\text { variables }\end{array}$} & \multicolumn{6}{|c|}{${ }^{1}$ Sign of determinants of Capital Structure } \\
\hline & & & & & & Tang & Prof & Grow & Size & Liq & NDTS \\
\hline $\begin{array}{c}{ }^{2} \text { Abd Wahaab } \\
\text { and Ramli } \\
\text { (2014) }\end{array}$ & 1997-2009 & $\begin{array}{l}\text { The } \\
\text { Determinants of } \\
\text { Capital Structure }\end{array}$ & $\begin{array}{c}\text { International } \\
\text { Journal of } \\
\text { Economics } \\
\text { and Financial } \\
\text { Issues }\end{array}$ & $\begin{array}{c}13 \text { Malaysian } \\
\text { Listed } \\
\text { Government } \\
\text { Linked } \\
\text { Companies }\end{array}$ & Leverage & $+* * *$ & $-*$ & & $-* * *$ & $\begin{array}{c}- \\
* * *\end{array}$ & \\
\hline $\begin{array}{c}{ }^{2} \text { Bevan and } \\
\text { Danbolt } \\
(2002)\end{array}$ & 1991 & $\begin{array}{l}\text { Re-examines the } \\
\text { relationship of } \\
\text { (Rajan\&Zingales } \\
\text { 1995) to } \\
\text { variations in } \\
\text { gearing measure } \\
\text { by examining } \\
\text { more debt } \\
\text { measure. }\end{array}$ & $\begin{array}{c}\text { Applied } \\
\text { Finance } \\
\text { Economics }\end{array}$ & $\begin{array}{c}822 \text { UK } \\
\text { Companies }\end{array}$ & Debt & $+* *$ & $-* * *$ & - & $+* * *$ & & \\
\hline $\begin{array}{c}\text { Deloof and } \\
\text { Verschueren } \\
1998\end{array}$ & $1992-1994$ & $\begin{array}{c}\text { Are leases and } \\
\text { debt substitutes? }\end{array}$ & $\begin{array}{c}\text { Journal of } \\
\text { Economics } \\
\text { and } \\
\text { Management }\end{array}$ & $\begin{array}{c}1,066 \\
\text { Non-financial } \\
\text { Belgian firms }\end{array}$ & Leases & $\begin{array}{c}+ \\
\text { without } \\
\text { STD } \\
\text { - with } \\
\text { STD }\end{array}$ & $-*$ & - & $+* * *$ & & \\
\hline $\begin{array}{c}\text { Frank and } \\
\text { Goyal (2009) }\end{array}$ & $1950-2003$ & $\begin{array}{l}\text { Examines the } \\
\text { factors affecting } \\
\text { publicly traded } \\
\text { American firms }\end{array}$ & $\begin{array}{c}\text { Financial } \\
\text { Management }\end{array}$ & & Leverage & $+* * *$ & $-* * *$ & & $+* * *$ & & \\
\hline $\begin{array}{l}\text { Gaud et al. } \\
\text { (2003) }\end{array}$ & $1991-2000$ & $\begin{array}{l}\text { The } \\
\text { Determinants of } \\
\text { the Capital } \\
\text { Structure }\end{array}$ & $\begin{array}{c}\text { European } \\
\text { Financial } \\
\text { Management }\end{array}$ & $\begin{array}{c}106 \text { Listed } \\
\text { Swiss } \\
\text { companies }\end{array}$ & Leverage & + & $-* * *$ & - & $+* * *$ & & \\
\hline $\begin{array}{c}\text { Huang \& } \\
\text { Song (2006) }\end{array}$ & $1994-2003$ & $\begin{array}{l}\text { The } \\
\text { Determinants of } \\
\text { Capital Structure }\end{array}$ & $\begin{array}{c}\text { China } \\
\text { Economic } \\
\text { Review }\end{array}$ & $\begin{array}{l}1200 \text { Chinese } \\
\text { listed } \\
\text { companies }\end{array}$ & Leverage & $+* * *$ & $-* * *$ & & $+* * *$ & & $-* * *$ \\
\hline $\begin{array}{c}{ }^{2} \text { Joseph Ooi, } \\
\text { (1999). }\end{array}$ & $1989-1996$ & $\begin{array}{l}\text { The } \\
\text { Determinants of } \\
\text { Capital Structure }\end{array}$ & $\begin{array}{c}\text { Journal of } \\
\text { Property } \\
\text { Investment \& } \\
\text { Finance }\end{array}$ & $\begin{array}{l}83 \text { property } \\
\text { companies } \\
\text { quoted in the } \\
\text { UK }\end{array}$ & Leverage & + & & - & $-*$ & & \\
\hline Author & $\begin{array}{c}\text { Data } \\
\text { Period }\end{array}$ & Focus & Journal & Sample & $\begin{array}{l}\text { Dependent } \\
\text { variables }\end{array}$ & Tang & $\begin{array}{r}{ }^{1} \text { Sign o } \\
\text { Prof }\end{array}$ & $\begin{array}{l}\text { erminar } \\
\text { Grow }\end{array}$ & $\begin{array}{l}\text { Capita } \\
\text { Size }\end{array}$ & $\begin{array}{l}\text { tructu } \\
\text { Liq }\end{array}$ & NDTS \\
\hline $\begin{array}{c}\text { Khrawish and } \\
\text { Khrawish }\end{array}$ & 2001-2005 & $\begin{array}{l}\text { Investigate what } \\
\text { are the }\end{array}$ & $\begin{array}{l}\text { Economics } \\
\text { and }\end{array}$ & $\begin{array}{c}150 \\
\text { companies on }\end{array}$ & Leverage & + & - & & + & & \\
\hline
\end{tabular}




\begin{tabular}{|c|c|c|c|c|c|c|c|c|c|c|c|}
\hline & & $\begin{array}{l}\text { determinants of } \\
\text { Capital Structure }\end{array}$ & Administration & $\begin{array}{c}\text { Amman } \\
\text { Stock } \\
\text { Exchange }\end{array}$ & & & & & & & \\
\hline $\begin{array}{c}{ }^{2} \text { Michaelas et } \\
\text { al. (1999) }\end{array}$ & 1986-1995 & $\begin{array}{l}\text { Financial Policy } \\
\text { and Capital } \\
\text { Structure Choice }\end{array}$ & $\begin{array}{l}\text { Small } \\
\text { Business } \\
\text { Economics }\end{array}$ & $\begin{array}{l}3500 \text { Choice } \\
\text { in U.K. } \\
\text { SMEs }\end{array}$ & Leverage & + & - & + & + & & $+*$ \\
\hline $\begin{array}{c}\text { Najjar\&Petrov } \\
\text { (2011) }\end{array}$ & 2005-2009 & $\begin{array}{c}\text { Capital Structure } \\
\text { of Insurance } \\
\text { Companies in } \\
\text { Bahrain }\end{array}$ & $\begin{array}{l}\text { International } \\
\text { Journal of } \\
\text { Business and } \\
\text { Management }\end{array}$ & $\begin{array}{c}25 \text { Insurance } \\
\text { Companies in } \\
\text { Bahrain }\end{array}$ & Leverage & $+*$ & + & - & $+* * *$ & $-*$ & \\
\hline $\begin{array}{c}\text { Ojah\& } \\
\text { Manrique } \\
\text { (2005) }\end{array}$ & 1998-1999 & $\begin{array}{l}\text { Determinants of } \\
\text { corporate debt } \\
\text { structure in a } \\
\text { privately } \\
\text { dominated debt } \\
\text { market }\end{array}$ & $\begin{array}{l}\text { Applied } \\
\text { Financial } \\
\text { Economics }\end{array}$ & $\begin{array}{l}\text { Spanish } \\
\text { capital } \\
\text { market }\end{array}$ & Leverage & & & & $+* *$ & & \\
\hline $\begin{array}{l}\text { Oke M. and } \\
\text { Obalade } \\
\text { A.(2015) }\end{array}$ & 2005-2012 & $\begin{array}{l}\text { Testing the } \\
\text { validity of } \\
\text { optimal capital } \\
\text { structure theory }\end{array}$ & $\begin{array}{l}\text { International } \\
\text { Journal of } \\
\text { Economics }\end{array}$ & $\begin{array}{c}6 \text { Nigerian oil } \\
\text { industry }\end{array}$ & Leverage & - & $+* * *$ & & $-* *$ & & \\
\hline Ozkan (2001) & 1984-1996 & $\begin{array}{l}\text { Determines } \\
\text { target capital } \\
\text { structure }\end{array}$ & $\begin{array}{l}\text { Journal of } \\
\text { Business } \\
\text { Finance and } \\
\text { Accounting }\end{array}$ & $\begin{array}{c}390 \\
\text { Non-financial } \\
\text { UK } \\
\text { Companies }\end{array}$ & Total debt & & - *** & - * & $+* * *$ & $\begin{array}{l}- \\
* * *\end{array}$ & - \\
\hline $\begin{array}{l}\text { Psillaki and } \\
\text { Daskalakis } \\
\text { (2008) }\end{array}$ & $1998-2002$ & $\begin{array}{l}\text { Are the } \\
\text { determinants of } \\
\text { capital structure } \\
\text { country or firm } \\
\text { specific? }\end{array}$ & $\begin{array}{c}\text { Small } \\
\text { Business } \\
\text { Economics, } \\
\text { Springer }\end{array}$ & $\begin{array}{c}3630 \text { SMEs } \\
\text { from Greece, } \\
\text { France, Italy } \\
\text { and } \\
\text { Portugal }\end{array}$ & Leverage & $\begin{array}{c}-* * * \\
\text { Except } \\
\text { in } \\
\text { Portugal } \\
\qquad(+)\end{array}$ & $\begin{array}{c}\text { - *** } \\
\text { Greece, } \\
\text { France, } \\
\text { Italy } \\
\text { - } \\
\text { Portugal }\end{array}$ & $\begin{array}{l}\text { - } \\
\text { Greece, } \\
\text { France, } \\
\text { Italy and } \\
\text { Portugal }\end{array}$ & $\begin{array}{c}+* * * \\
\text { Greece } \\
+* * \\
\text { Portugal } \\
+* \\
\text { France } \\
\quad+ \\
\text { Italy }\end{array}$ & & \\
\hline $\begin{array}{c}\text { Ragan and } \\
\text { Zingales } \\
\text { (1995) }\end{array}$ & 1987-1991 & $\begin{array}{l}\text { Tests wither } \\
\text { capital structure } \\
\text { of the G7 (UK, } \\
\text { US, Japan, } \\
\text { France, Canada, } \\
\text { Germany, Italy) } \\
\text { is affected by the } \\
\text { same factors as } \\
\text { US firms }\end{array}$ & $\begin{array}{l}\text { Journal of } \\
\text { Finance }\end{array}$ & $\begin{array}{c}\text { G-7 countries } \\
\text { (UK, US, } \\
\text { Japan, } \\
\text { Germany, } \\
\text { France, Italy } \\
\text { and Canada) }\end{array}$ & 更 & $\begin{array}{c}+* * * \\
\text { UK, US, } \\
\text { Japan, } \\
\text { France, } \\
\text { Canada } \\
+* * \\
\text { Germany }\end{array}$ & $\begin{array}{c}\text { - *** } \\
\text { US, } \\
\text { Japan } \\
\text { - ** } \\
\text { Canada }\end{array}$ & $\begin{array}{c}\text { - *** } \\
\text { UK, US, } \\
\text { France, } \\
\text { Canada } \\
\text { - ** } \\
\text { France }\end{array}$ & $\begin{array}{c}+ \text { except } \\
\text { in } \\
\text { Germany } \\
(-) \\
+* * * \\
\text { US, } \\
\text { Japan, } \\
\text { Germany, } \\
\text { UK, } \\
\text { Canada }\end{array}$ & & \\
\hline Author & Data & Focus & Journal & Sample & Dependent & & ${ }^{1}$ Sign o & erminan & f Capital & ucture & \\
\hline
\end{tabular}




\begin{tabular}{|c|c|c|c|c|c|c|c|c|c|c|c|}
\hline & Period & & & & variables & Tang & Prof & Grow & Size & Liq & NDTS \\
\hline${ }^{2}$ Song (2005) & $1992-2000$ & $\begin{array}{l}\text { this study } \\
\text { investigates } \\
\text { capital } \\
\text { structure } \\
\text { determinants }\end{array}$ & $\begin{array}{l}\text { The Royal } \\
\text { Institute of } \\
\text { technology } \\
\text { Centre }\end{array}$ & $\begin{array}{c}6000 \\
\text { Swedish } \\
\text { companies }\end{array}$ & leverage & $+* * *$ & $-* * *$ & - *** & $+* * *$ & & $-* *$ \\
\hline $\begin{array}{c}\text { Sritharan, V } \\
\text { (2014). }\end{array}$ & $2008-2012$ & $\begin{array}{l}\text { Investigate what } \\
\text { are the } \\
\text { determinants of } \\
\text { Capital Structure }\end{array}$ & $\begin{array}{l}\text { International } \\
\text { Journal of } \\
\text { Economics }\end{array}$ & $\begin{array}{l}28 \text { Colombo } \\
\text { stock } \\
\text { exchange in } \\
\text { Srilanka }\end{array}$ & leverage & - & - & - & + & - & + \\
\hline $\begin{array}{c}{ }^{2} \text { Titman and } \\
\text { Wessels } \\
\text { (1988) }\end{array}$ & 1974-1982 & $\begin{array}{l}\text { Investigate what } \\
\text { are the } \\
\text { determinants of } \\
\text { Capital Structure }\end{array}$ & $\begin{array}{l}\text { Journal of } \\
\text { Finance }\end{array}$ & 469 US firms & $\begin{array}{l}\text { Long term } \\
\text { debt, } \\
\text { short-term } \\
\text { debt and } \\
\text { convertible } \\
\text { debt }\end{array}$ & - & - & + & - & & - \\
\hline $\begin{array}{l}{ }^{2} \text { Upneja A. } \\
\text { and Dalbor } \\
\text { M.C. (2001). }\end{array}$ & 1991-1998 & $\begin{array}{l}\text { An Examination } \\
\text { of Capital } \\
\text { Structure in the } \\
\text { Restaurant } \\
\text { Industry }\end{array}$ & $\begin{array}{l}\text { International } \\
\text { Journal of } \\
\text { Contemporary } \\
\text { Hospitality } \\
\text { Management }\end{array}$ & $\begin{array}{c}393 \\
\text { restaurant } \\
\text { firms listed } \\
\text { on the stock } \\
\text { exchange } \\
\text { classification } \\
\text { code of } 5812\end{array}$ & Leverage & & & & & & \\
\hline Wald (1999) & 1991-1992 & $\begin{array}{l}\text { Investigates the } \\
\text { factors affecting } \\
\text { the capital } \\
\text { structure }\end{array}$ & $\begin{array}{l}\text { Journal of } \\
\text { Finance } \\
\text { Research }\end{array}$ & $\begin{array}{l}4404 \text { French, } \\
\text { German, UK } \\
\text { and Japanese } \\
\text { Companies }\end{array}$ & Leverage & & $\begin{array}{c}- \\
\text { UK, US, } \\
\text { Japan, } \\
\text { France } \\
\text { Germany }\end{array}$ & $\begin{array}{c}- \\
\text { UK, US, } \\
\text { Japan, } \\
\text { France } \\
\quad+ \\
\text { Germany }\end{array}$ & $\begin{array}{c}+ \\
\text { UK, US, } \\
\text { Japan } \\
- \\
\text { Germany, } \\
\text { France }\end{array}$ & & $\begin{array}{c}- \\
\text { UK, US, } \\
\text { Japan, } \\
\text { France } \\
\text { Germany }\end{array}$ \\
\hline
\end{tabular}

Note:

$* * *, * *$, and $*$ mean statistically different from zero at the $1 \%, 5 \%$ and $10 \%$ level, respectively

1- Even there are many variables have been investigated in the literature, this study selects only seven variables which are tangibility (Tang), profitability (Prof), Growth (Grow), Size (Size), Liquidity (Liq) and Non debt tax shield (NDTS).

2- These studies use more than one model to measure Leverage. However, their result that are mentioned in this table are suitable to this study since they are resulted from applying the same model that this study applies to measure leverage which is the one that defined as the ratio of total debt to book value of total assets 
Table 3.1. The Distribution of Oil and Gas Firms According to Region

\begin{tabular}{cc}
\hline Category & Number of companies \\
\hline Oceania & 57 \\
\hline Europe & 74 \\
\hline Russia & 12 \\
\hline Asia & 81 \\
\hline South America & 12 \\
\hline Africa & 9 \\
\hline The United State & 83 \\
\hline The United Kingdom & 18 \\
\hline total & $\mathbf{3 4 6}$
\end{tabular}

Table 3.2. Summary of variables, proxy and References

\begin{tabular}{|c|c|c|c|}
\hline & Variables & Proxy & References \\
\hline $\begin{array}{l}\text { Dependent } \\
\text { variable }\end{array}$ & Leverage & $\begin{array}{c}\text { ratio of total debt to book value } \\
\text { of total assets }\end{array}$ & $\begin{array}{l}\text { Ozkan (2001); } \\
\text { Rajan and Zingales (1995) }\end{array}$ \\
\hline \multirow{6}{*}{$\begin{array}{l}\text { Independent } \\
\text { Variables }\end{array}$} & Tangibility & $\begin{array}{c}\text { Tangible Fixed Assets / Total } \\
\text { Assets }\end{array}$ & $\begin{array}{c}\text { Rajan and Zingales, (1995); } \\
\text { Ozkan (2001) }\end{array}$ \\
\hline & Profitability & $\begin{array}{c}\text { Earnings before interest and tax } \\
\text { / Total Assets }\end{array}$ & $\begin{array}{c}\text { Rajan and Zingales, (1995); } \\
\text { Ozkan, (2001) }\end{array}$ \\
\hline & Size & logarithm of total assets & $\begin{array}{l}\text { Padron et al (2005) } \\
\text { and Frank \& Goyal (2009) }\end{array}$ \\
\hline & Growth & $\begin{array}{c}\text { percentage increase in total } \\
\text { assets }\end{array}$ & Titman \&Wessele(1988) \\
\hline & Liquidity & $\begin{array}{c}\text { Current Assets/ Current } \\
\text { Liabilities }\end{array}$ & $\begin{array}{l}\text { Deesomsak et al (2004); } \\
\text { Ozkan (2001) }\end{array}$ \\
\hline & $\begin{array}{l}\text { Non-debt tax } \\
\text { shield }\end{array}$ & Depreciation / Total assets & $\begin{array}{c}\text { Titman and Wessels (1988); } \\
\text { Ozkan (2001) }\end{array}$ \\
\hline
\end{tabular}




\section{Macrothink}

Asian Journal of Finance \& Accounting

ISSN 1946-052X

2017, Vol. 9, No. 1

Table 3.4. summarizes the hypothesized, expected theoretical signs of the independent variables depending on the theoretical and empirical literature

\begin{tabular}{c|c|c|c|c|c|c}
\hline $\begin{array}{c}\text { Explanatory } \\
\text { Variable }\end{array}$ & $\begin{array}{c}\text { Hypothesis } \\
\text { signs }\end{array}$ & $\begin{array}{c}\text { Mostly } \\
\text { reported in the } \\
\text { empirical } \\
\text { literature }\end{array}$ & $\begin{array}{c}\text { Pecking order } \\
\text { theory }\end{array}$ & $\begin{array}{c}\text { Trade-off } \\
\text { theory }\end{array}$ & $\begin{array}{c}\text { Agency cost } \\
\text { theory }\end{array}$ & expected sign \\
\hline Tangibility & + & + & + & + & + & + \\
\hline Profitability & - & - & - & + & $?$ & - \\
\hline Growth & - & + & + & + & + & + \\
\hline Size & + & + & - & $?$ & + & + \\
\hline Liquidity & - & - & $?$ & - & $?$ \\
\hline Non-debt tax \\
shield
\end{tabular}

$\checkmark$ The theoretical signs of explanatory variables are presented in summary based on the previous capital structure theories and were used by different researchers such as Titman and Wessels (1988), Haris and Ravive (1991), Gaud et al (2005),

$\checkmark$ "+" Represents that the specified theory suggests a positive relationship between the explanatory variable and leverage.

$\checkmark$ "-" Represents that the specified theory proposes a negative relationship between the explanatory variable and leverage.

$\checkmark$ "?" Represents that there is no clear prediction. 
Table 4.4. Summary of Descriptive Statistic after removal of outliers.

\begin{tabular}{|c|c|c|c|c|c|c|c|}
\hline Variable & Obs. & No. of Fs & Mean & Median & Std. Dev. & Min & Max \\
\hline TDA & 4181 & 346 & 0.2457 & 0.2290 & 0.1717 & 0.0000 & 0.7136 \\
\hline Tangibility & 4181 & 346 & 0.5233 & 0.5401 & 0.2589 & 0.0422 & 0.9537 \\
\hline Profitability & 4181 & 346 & 0.0920 & 0.0832 & 0.0942 & -0.2216 & 0.3967 \\
\hline Growth & 4181 & 346 & 0.1622 & 0.1132 & 0.2530 & -0.4858 & 1.0000 \\
\hline Size & 4181 & 346 & 15.9889 & 15.6293 & 2.6866 & 9.9686 & 23.2964 \\
\hline Liquidity & 4181 & 346 & 1.7761 & 1.2366 & 2.0473 & 0.2246 & 15.6961 \\
\hline NDTS & 4181 & 346 & 0.0473 & 0.0412 & 0.0317 & 0.0000 & 0.1638 \\
\hline
\end{tabular}

Notes: The dependent variable TDA is defined as the ratio of total debt to book value of total assets.

"Tangibility" is the ratio of fixed assets to total assets. "Profitability" is the ratio of EBITD to total assets.

"Growth" is the ratio of Percentage increase (change) in total assets (total assets current Year minus total assets previous Year to total assets current year "Size" is the natural logarithm of assets. "Liquidity" is the ratio of current assets to current liabilities. "NDTS" is the ratio of annual depreciation expense to total assets.

Table 4.5. Correlation Analysis

\begin{tabular}{|c|c|c|c|c|c|c|c|}
\hline Variable & TDA & TANG & PROF & GROW & SIZE & LIQ & NDTS \\
\hline TDA & 1 & & & & & & \\
\hline Tangibility & $0.249 * * *$ & 1 & & & & & \\
\hline Profitabilit & $-0.238 * * *$ & -0.006 & 1 & & & & \\
\hline \multicolumn{8}{|l|}{$\mathbf{y}$} \\
\hline Growth & $0.030 * *$ & 0.002 & $0.076 * * *$ & 1 & & & \\
\hline Size & $0.072 * * *$ & 0.005 & $0.159 * * *$ & $-0.127 * * *$ & 1 & & \\
\hline Liquidity & $-0.317 * * *$ & $-0.285 * * *$ & -0.033 & $0.047 * * *$ & $-0.136 * * *$ & 1 & \\
\hline NDTS & $-0.081 * * *$ & $0.422 * * *$ & $0.142 * * *$ & $-0.15 * * *$ & $-0.095 * * *$ & $-0.219 * * *$ & 1 \\
\hline
\end{tabular}

Notes: The dependent variable TDA is defined as the ratio of total debt to book value of total assets.

"Tangibility" is the ratio of fixed assets to total assets. "Profitability" is the ratio of EBITD to total assets.

"Growth" is the ratio of Percentage increase (change) in total assets (total assets current Year minus total assets previous Year to total assets current year "Size" is the natural logarithm of assets. "Liquidity" is the ratio of current assets to current liabilities. "NDTS" is the ratio of annual depreciation expense to total assets. 
Table 4.6. Regression Result of TDA and the independents Variables

\begin{tabular}{|c|c|c|c|c|}
\hline Variables & $\begin{array}{l}\text { All periods } \\
(2000-2014)\end{array}$ & $\begin{array}{l}\text { Pre-crisis period } \\
\quad(2000-2006)\end{array}$ & $\begin{array}{l}\text { Crisis period } \\
(2007-2009)\end{array}$ & $\begin{array}{l}\text { Post-crisis period } \\
\quad(2010-2014)\end{array}$ \\
\hline \multirow[t]{2}{*}{ Tangibility } & $0.1639 * * *$ & $0.1678 * * *$ & $0.2147 * * *$ & $0.1583 * * *$ \\
\hline & $(0.0115)$ & $(0.0180)$ & $(0.0308)$ & $(0.0175)$ \\
\hline \multirow[t]{2}{*}{ Profitability } & $-0.4189 * * *$ & $-0.5389 * * *$ & $-0.3453 * * *$ & $-0.3601 * * *$ \\
\hline & $(0.0279)$ & $(0.0438)$ & $(0.0760)$ & $(0.0434)$ \\
\hline \multirow[t]{2}{*}{ Growth } & 0.0173 & $0.0257^{*}$ & -0.0105 & 0.0162 \\
\hline & $(0.0122)$ & $(0.0165)$ & $(0.0335)$ & $(0.0221)$ \\
\hline \multirow[t]{2}{*}{ Size } & $0.0038 * * *$ & $0.0057 * * *$ & $0.0018 * * *$ & $0.0039 * *$ \\
\hline & $(0.0009)$ & $(0.0016)$ & $(0.0025)$ & $(0.0013)$ \\
\hline \multirow[t]{2}{*}{ Liquidity } & $-0.0245 * * *$ & $-0.0128 * * *$ & $-0.0081 * * *$ & $-0.0348 * * *$ \\
\hline & $(0.0012)$ & $(0.0010)$ & $(0.0011)$ & $(0.0025)$ \\
\hline \multirow[t]{2}{*}{ NDTS } & $-1.0531 * * *$ & $-0.5289 * * *$ & $-1.2707 * * *$ & $-1.3561 * * *$ \\
\hline & $(0.0942)$ & $(0.1520)$ & $(0.2490)$ & $(0.1341)$ \\
\hline \multirow[t]{2}{*}{ Pre-crisis Dummy2001 } & 0.0108 & 0.00863 & & \\
\hline & $(0.0154)$ & $(0.0153)$ & & \\
\hline \multirow[t]{2}{*}{ Pre-crisis Dummy2002 } & 0.00551 & 0.000416 & & \\
\hline & $(0.0154)$ & $(0.0154)$ & & \\
\hline \multirow[t]{2}{*}{ Pre-crisis Dummy2003 } & -0.00629 & -0.00824 & & \\
\hline & $(0.0146)$ & $(0.0146)$ & & \\
\hline \multirow[t]{2}{*}{ :-crisis Dummy2004 } & -0.00751 & -0.00873 & & \\
\hline & $(0.0145)$ & $(0.0144)$ & & \\
\hline \multirow[t]{2}{*}{ Pre-crisis Dummy2005 } & $-0.0238^{*}$ & -0.0222 & & \\
\hline & $(0.0145)$ & $(0.0143)$ & & \\
\hline \multirow[t]{2}{*}{ Pre-crisis Dummy2006 } & -0.0144 & -0.0118 & & \\
\hline & $(0.0145)$ & $(0.0145)$ & & \\
\hline Crisis Dummy $\quad 2007$ & $-0.0267 *$ & & & \\
\hline
\end{tabular}


(0.0140)

\begin{tabular}{|ll|l|l|l|}
\hline Crisis Dummy & $\mathbf{2 0 0 8}$ & -0.0152 & 0.0108 \\
\hline Crisis Dummy & $\mathbf{2 0 0 9}$ & $-0.0246^{*}$ & $(0.0124)$ \\
\hline
\end{tabular}

\section{Post-Crisis}

$-0.0309 * *$

Dummy2010

(0.0138)

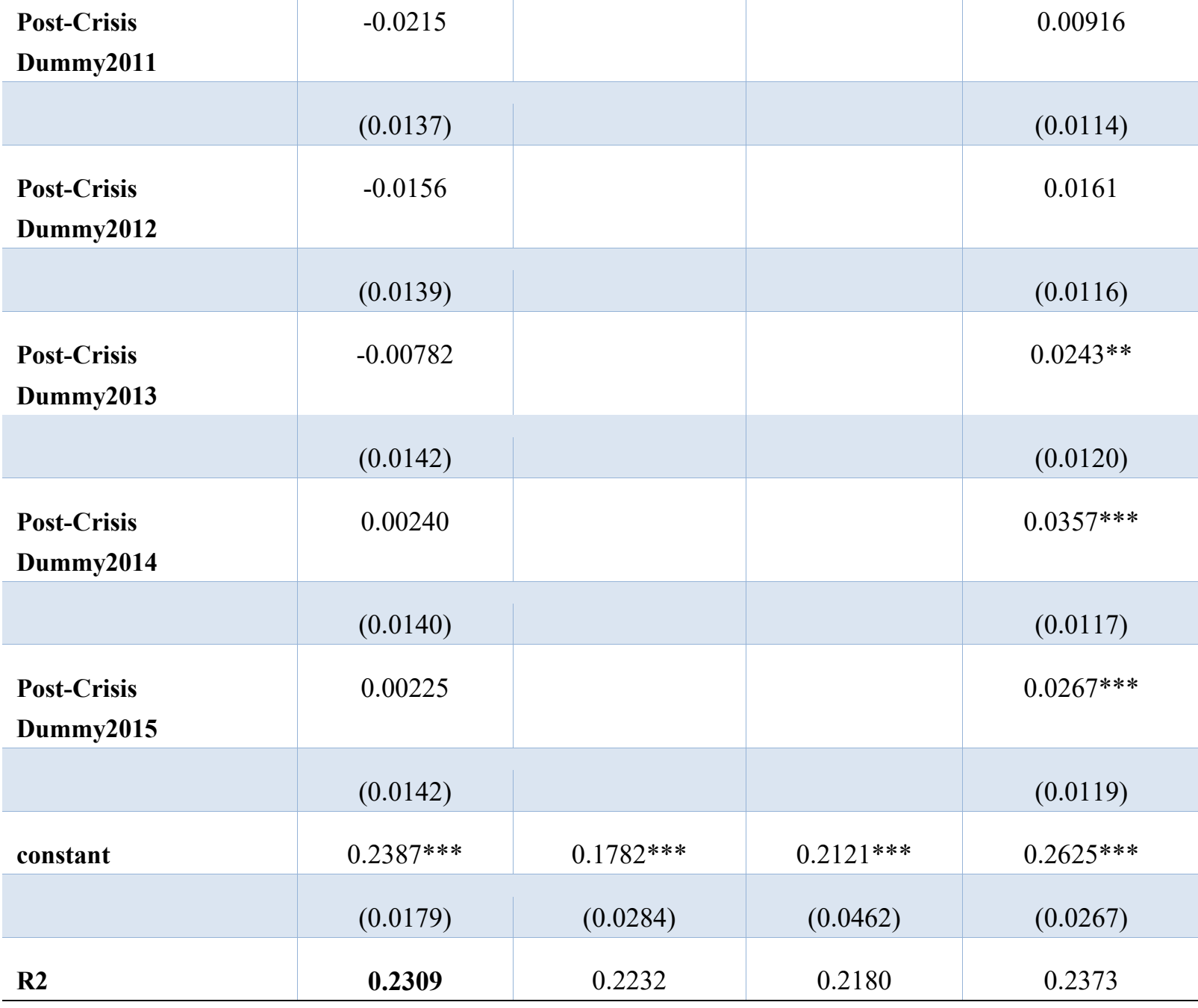

Notes: The dependent variable TDA is defined as the ratio of total debt to total assets. "Tangibility" is the ratio of fixed assets to total assets. "Profitability" is the ratio of EBITD to total assets. "Growth" is the ratio of Percentage increase (change) in total assets (total assets current Year minus total assets previous Year to total assets current year "Size" is the natural logarithm of assets. "Liquidity" is the ratio of current assets to current liabilities. "NDTS" is the ratio of annual depreciation expense to total assets. "Age "of the firm in years at the time of the survey. 
$\left(^{* * *}\right)$ significant at the $1 \%$ level; $\left(^{* *}\right)$ significant at the $5 \%$ level; $(*)$ significant at the $10 \%$ level

Table 4.7. The Impact of the Global Financial Crisis on the Descriptive Statistics, (mean)

\begin{tabular}{c|c|c|c}
\hline $\begin{array}{c}\text { Explanatory } \\
\text { Variable }\end{array}$ & $\begin{array}{c}\text { Post-crisis period } \\
\mathbf{( 2 0 1 0 - 2 0 1 4 )}\end{array}$ & $\begin{array}{c}\text { Crisis period } \\
\mathbf{( 2 0 0 7 - 2 0 0 9 )}\end{array}$ & $\begin{array}{c}\text { Pre-crisis period } \\
\mathbf{( 2 0 0 0 - 2 0 0 6 )}\end{array}$ \\
\hline TDA & 0.2422 & 0.2298 & 0.2534 \\
\hline Tangibility & 0.5296 & 0.5076 & 0.523 \\
\hline Profitability & 0.1088 & 0.1117 & 0.0724 \\
\hline Growth & 0.1975 & 0.1896 & 0.1238 \\
\hline Size & 15.4347 & 16.0171 & 16.4411 \\
\hline Liquidity & 1.9493 & 2.2527 & 1.6871 \\
\hline NDTS & 0.0504 & 0.0443 & 0.0457 \\
\hline
\end{tabular}

Notes: The dependent variable TDA is defined as the ratio of total debt to total assets. "Tangibility" is the ratio of fixed assets to total assets. "Profitability"' is the ratio of EBITD to total assets. "Growth" is the ratio of Percentage increase (change) in total assets (total assets current Year minus total assets previous Year to total assets current year "Size" is the natural logarithm of assets. "Liquidity" is the ratio of current assets to current liabilities. "NDTS" is the ratio of annual depreciation expense to total assets. 
Table 4.8. Comparison of the Determinants During the Three Different Periods

\begin{tabular}{c|c|c|c|c}
\hline $\begin{array}{c}\text { Explanatory } \\
\text { Variable }\end{array}$ & All period & Pre-crisis period & Crisis period & Post-crisis period \\
\hline Tangibility & $\mathbf{( 2 0 0 0 - 2 0 1 4 )}$ & $\mathbf{( 2 0 0 0 - 2 0 0 6 )}$ & $\mathbf{( 2 0 0 7 - 2 0 0 9 )}$ & $\mathbf{( 2 0 1 0 - 2 0 1 4 )}$ \\
\hline Profitability & $-0.41639 * * *$ & $0.1678 * * *$ & $0.2147 * * *$ & $0.1583 * * *$ \\
\hline Growth & 0.0173 & $-0.5389 * * *$ & $-0.3453 * * *$ & $-0.3601 * * *$ \\
\hline Size & $0.0038 * * *$ & $0.0257 *$ & 0.0105 & 0.0162 \\
\hline Liquidity & $-0.0245 * * *$ & $-0.0128 * * *$ & $-0.0081 * * *$ & $-0.0348 * * *$ \\
\hline Non-debt tax shield & $-1.0531 * * *$ & $-0.5289 * * *$ & $-1.2707 * * *$ & $-1.3561 * * *$ \\
\hline constant & $0.2387 * * *$ & $0.1933 *$ & $0.1933 * *$ & $0.2551 * * *$ \\
\hline R-squared & 0.2309 & 0.2232 & 0.2180 & 0.2373 \\
\hline
\end{tabular}

Notes: "Tangibility" is the ratio of fixed assets to total assets. "Profitability"' is the ratio of EBITD to total assets. "Growth" is the ratio of Percentage increase (change) in total assets (total assets current Year minus total assets previous Year to total assets current year "Size" is the natural logarithm of assets. "Liquidity" is the ratio of current assets to current liabilities. "NDTS" is the ratio of annual depreciation expense to total assets. (***) significant at the $1 \%$ level; (**) significant at the $5 \%$ level; $(*)$ significant at the $10 \%$ level

Table 4.9. Summary of Results Supporting Capital Structure Theories

\begin{tabular}{ccc}
\hline Variable & Effect & Theory \\
\hline Tangibility & + & Pecking order theory, Trade-off theory, Agency cost theory \\
\hline Profitability & - & Pecking order theory \\
\hline Growth & + & Pecking order theory \\
\hline Size & + & Pecking order theory, Agency cost theory \\
\hline Liquidity & - & Trade-off theory \\
\hline NDTS & &
\end{tabular}

